\title{
Effect of formononetin from Trifolium pratense L. on oxidative stress, energy metabolism and inflammatory response after cerebral ischemia-reperfusion injury in mice
}

\author{
Xueyan WANG ${ }^{1 *}$, Tie LI' ${ }^{1 *}$, Kun DONG ${ }^{1 *}$ (1)
}

\begin{abstract}
Cerebral ischemia-reperfusion injury (CIRI) is one of the main diseases leading to death and disability. Studying the role and mechanism of drugs in mitigating CIRI is of great significance. In the present study, the effect of formononetin from Trifolium pratense L. on oxidative stress, energy metabolism impairment and inflammatory response after cerebral ischemia-reperfusion injury (CIRI) in mice were investigated. Formononetin was extracted from Trifolium pratense L. and was purified. The mice were treated with formononetin for six days. Then, the CIRI model was established. After $24 \mathrm{~h}$ of reperfusion, compared with model group, in formononetin group, the neurological deficit score, cerebral water content and cerebral infarction rate were significantly decreased, the brain tissue nitric oxide and malondialdehyde levels were significantly decreased, the brain tissue superoxide dismutase level was significantly increased, the brain tissue $\mathrm{Na}^{+}-\mathrm{K}^{+}$-ATPase, $\mathrm{Ca}^{2+}-\mathrm{Mg}^{2+}$-ATPase and $\mathrm{Ca}^{2+}$-ATPase activities were significantly increased, and the brain tissue tumor necrosis factor $\alpha$, interleukin $1 \beta$ and interleukin 6 levels were significantly decreased. In conclusion, formononetin from Trifolium pratense L. can reduce the oxidative stress, energy metabolism impairment and inflammatory response in brain tissues, thus mitigating the CIRI in mice.
\end{abstract}

Keywords: formononetin; cerebral ischemia-reperfusion injury; oxidative stress; energy metabolism; inflammatory response.

Practical Application: Formononetin has beneficial effect on cerebral ischemia-reperfusion injury and may be developed as a potential candidate for prevention and treatment of cerebral ischemia-reperfusion injury.

\section{Introduction}

Ischemic stroke accounts for about $80 \%$ of cerebrovascular diseases. It is mainly due to the cerebral artery atherosclerosis, thrombus shedding and vascular damage, which lead to the cerebral artery embolism, resulting in the cerebral tissue ischemia and necrosis (Wang et al., 2019). Clinically, the cerebral blood circulation is improved by thrombolysis and use of anticoagulant drugs. However, due to the risk of bleeding and narrow treatment time window, the vast majority of patients cannot obtain effective treatment. In addition, the vascular recanalization leads to the cerebral ischemia-reperfusion injury (CIRI) (Zhang et al., 2021). At present, there is a lack of specific drugs for CIRI in clinic, so it is still a research focus to seek new drugs with high efficiency and low toxicity for CIRI. Trifolium pratense L. (red clover) is a medicinal plant widely distributed in Europe, United States, New Zealand and China. It is being marketed for use in alleviation of hot flashes and other menopausal symptoms (Kanadys et al., 2020). Formononetin is one of the main active components of Trifolium pratense L. (Medjakovic \& Jungbauer, 2008). Formononetin belongs to isoflavones, and has a variety of pharmacological activities, such as tumor inhibition, anti-oxidation, anti-inflammation, anti-hypertension and estrogenic like effects (Chen et al., 2011; Sun et al., 2013; Lima Cavendish et al., 2015). Formononetin can prevent the myocardial from ischemia-reperfusion injury in rats by suppressing the ROS-TXNIP-NLRP3 pathway (Wang et al., 2020). It is found that many plants or their extracts have the antioxidant, anti-inflammatory and other activities (Costa et al., 2020; Hu et al., 2021; Sultan et al., 2021). This study was to investigate the effect of formononetin from Trifolium pratense L. on oxidative stress, energy metabolism and inflammatory response after CIRI in mice.

\section{Materials and methods}

\subsection{Extraction of formononetin from Trifolium pratense $L$. and purification}

A $1 \mathrm{~kg}$ dry Trifolium pratense L. was crushed into powder, and was placed in the microwave extractor. Then, $5 \mathrm{~L} 80 \%$ ethanol water solution was added. The microwave-assisted extraction (power $50 \mathrm{~W}$ ) was carried out for $1 \mathrm{~h}$. After filtering and vacuum concentration, the residue was suspended with water. Ethyl acetate was added to extract. The extraction solution was concentrated by vacuum. The residue was dissolved in $5 \% \mathrm{Na}_{2} \mathrm{CO}_{3}$ solution. Then, $1 \mathrm{~mol} / \mathrm{L}$ hydrochloric acid was added to the solution for precipitating. The precipitate was up-loaded on the macroporous resin column, followed by gradient elution. The target elution solution was collected, and was concentrated to a certain degree. After standing, the crystals were precipitated out. The crystals were dissolved in ethanol by refluxing, followed by cooling and crystallization. After filtering, the final crystals were obtained, which were the final formononetin product. 


\subsection{Grouping and treatment of animals}

The flow chart of animal experiments was shown in Figure 1. Sixty clean-grade male KM mice (18-22 g) were divided into sham-operated, model, formononetin and nimodipine groups, 15 mice in each group. The formononetin group was administrated with $20 \mathrm{mg} / \mathrm{kg}$ formononetin by intraperitoneal injection. The nimodipine group was administrated with $2 \mathrm{mg} / \mathrm{kg}$ nimodipine by intraperitoneal injection. The other two groups were given the same volume of normal saline by intraperitoneal injection. The injection was performed once per day, and the treatment lasted for six continuous days.

\subsection{Modeling of CIRI}

One hour after the last drug injection, the CIRI model was established in model, formononetin and nimodipine groups. The mice were anesthetized with $2 \%$ sodium pentobarbital and fixed on the operating table. The hair in the middle of the neck was carefully shaved, and the skin was disinfected with iodophor alcohol. A $1.5 \mathrm{~cm}$-long longitudinal incision was made. The common carotid artery, internal carotid artery and external carotid artery were exposed. The distal end of external carotid artery was ligated. An incision was made at the heatproximal end of external carotid artery. A nylon thread was inserted through the incision into the internal carotid artery until encountering resistance. The nylon thread was fixed, and the skin was sutured. After $30 \mathrm{~min}$ of ischemia, the nylon thread was slowly pulled out, followed by reperfusion for $24 \mathrm{~h}$. In sham-operated group, the operation steps were the same with other groups, but the nylon thread was not inserted into the internal carotid artery.

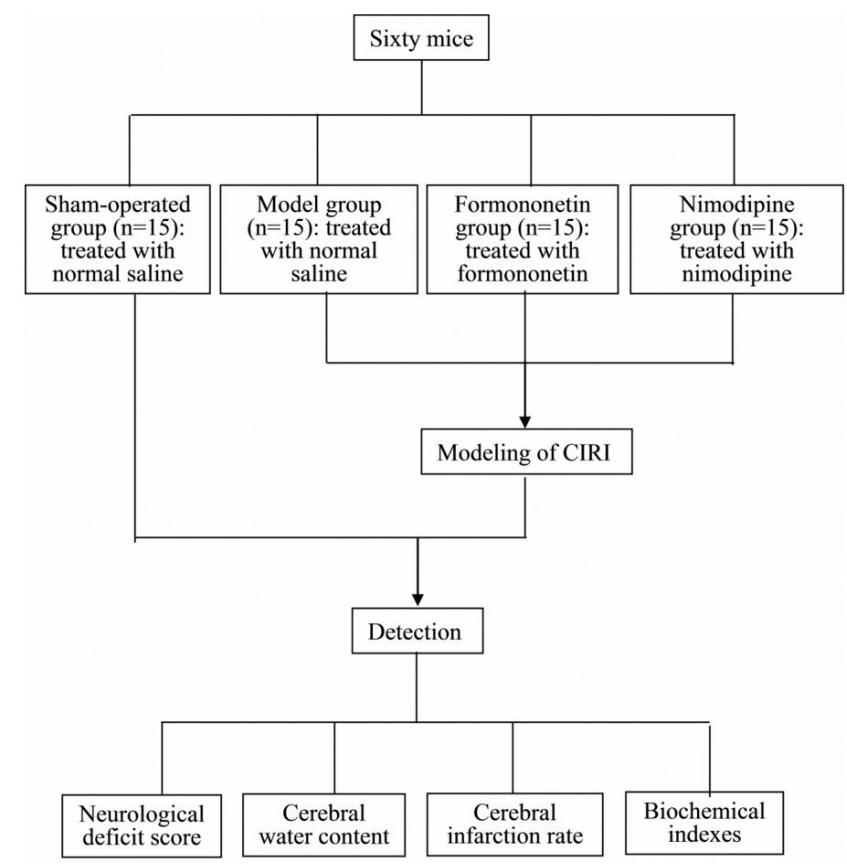

Figure 1. Flow chart of animal experiments.

\subsection{Evaluation of neurological deficit}

After $24 \mathrm{~h}$ from the reperfusion, five mice in each group were taken. The neurological deficit scoring was blindly performed by a single examiner using a 5-point scale as follows (Longa et al., 1989): no neurological deficit, 0 point; failure to extend the right forepaw fully, 1 point; circling to the right, 2 points; falling to the right, 3 points; did not walk spontaneously and had depressed levels of consciousness, 4 points. The higher the score was, the more serious the neurological deficit was.

\subsection{Measurement of cerebral water content}

After neurological deficit scoring, five mice in each group were taken. The mice were killed and decapitated quickly. The ischemic hemisphere was separated. The residual blood on the surface was sucked dry with filter paper. The brain tissues were weighed on the electronic balance to obtain the wet mass. Then, the brain tissues were dried in oven at $105^{\circ} \mathrm{C}$ to constant weight, and the dry mass was obtained. The brain water content was obtained as follows: water content $(\%)=[$ (wet mass - dry mass) / wet mass] $\times 100 \%$.

\subsection{Measurement of cerebral infarction rate}

Five mice in each group were taken. After the mice were killed, the brain was carefully separated. After cleaning with normal saline, the brain tissues were frozen at $-20^{\circ} \mathrm{C}$ for $0.5 \mathrm{~h}$. The coronal sections of brain were prepared. The sections were quickly immersed in $0.05 \%$ 2,3,5-triphenyltetrazole chloride solution (TTC) at $37^{\circ} \mathrm{C}$ for staining. After $15 \mathrm{~min}$, the sections were fixed in $10 \%$ formalin for $30 \mathrm{~min}$. The TTC-stained sections were scanned and photographed. Image processing software was used to calculate the percentage of infarct area in the total brain, that was, the cerebral infarction rate.

\subsection{Determination of biochemical indexes}

Five mice in each group were taken. The brain tissues were separated, and were homogenized with ice-cold normal saline. After centrifugation, the supernatant was obtained. The oxidative stress indexes including nitric oxide (NO), malondialdehyde (MDA) and superoxide dismutase (SOD) were measured by chemical colorimetry. The energy metabolism indexes including $\mathrm{Na}^{+}-\mathrm{K}^{+}$-ATPase, $\mathrm{Ca}^{2+}-\mathrm{Mg}^{2+}$-ATPase and $\mathrm{Ca}^{2+}$-ATPase activities were detected using the corresponding kits. The inflammatory factors including tumor necrosis factor $\alpha$ (TNF- $\alpha)$, interleukin $1 \beta$ (IL-1 $\beta$ ) and interleukin 6 (IL-6) were measured by enzyme linked immunosorbent assay.

\subsection{Statistical analysis}

Data presented were presented as mean \pm SEM, and were analyzed using SPSS 19.0 statistical software package. The comparisons among various groups were made using one way analysis of variance followed by a Newman-Keuls post-hoc test. $\mathrm{P}<0.05$ was taken to represent the statistically significant difference. 


\section{Results}

\subsection{Effects of formononetin on neurological deficit score, cerebral water content and cerebral infarction rate in CIRI mice}

After $24 \mathrm{~h}$ of reperfusion, the neurological deficit score, cerebral water content and cerebral infarction rate in model, formononetin and nimodipine groups were significantly $(\mathrm{P}<0.05)$ higher than those in sham-operated group, respectively. Each index in formononetin and nimodipine groups was significantly $(\mathrm{P}<0.05)$ decreased compared with model group, respectively (Figure 2).

\subsection{Effects of formononetin on brain tissue oxidative stress indexes in CIRI mice}

Figure 3 showed that, after $24 \mathrm{~h}$ of reperfusion, the brain tissue NO and MDA levels in model, formononetin and nimodipine groups were significantly $(\mathrm{P}<0.05)$ higher than those in sham-operated group, respectively, and the brain tissue SOD level in model, formononetin and nimodipine groups was significantly $(\mathrm{P}<0.05)$ lower than that in sham-operated group, respectively. Compared with model group, in formononetin and nimodipine groups the $\mathrm{NO}$ and MDA levels were significantly
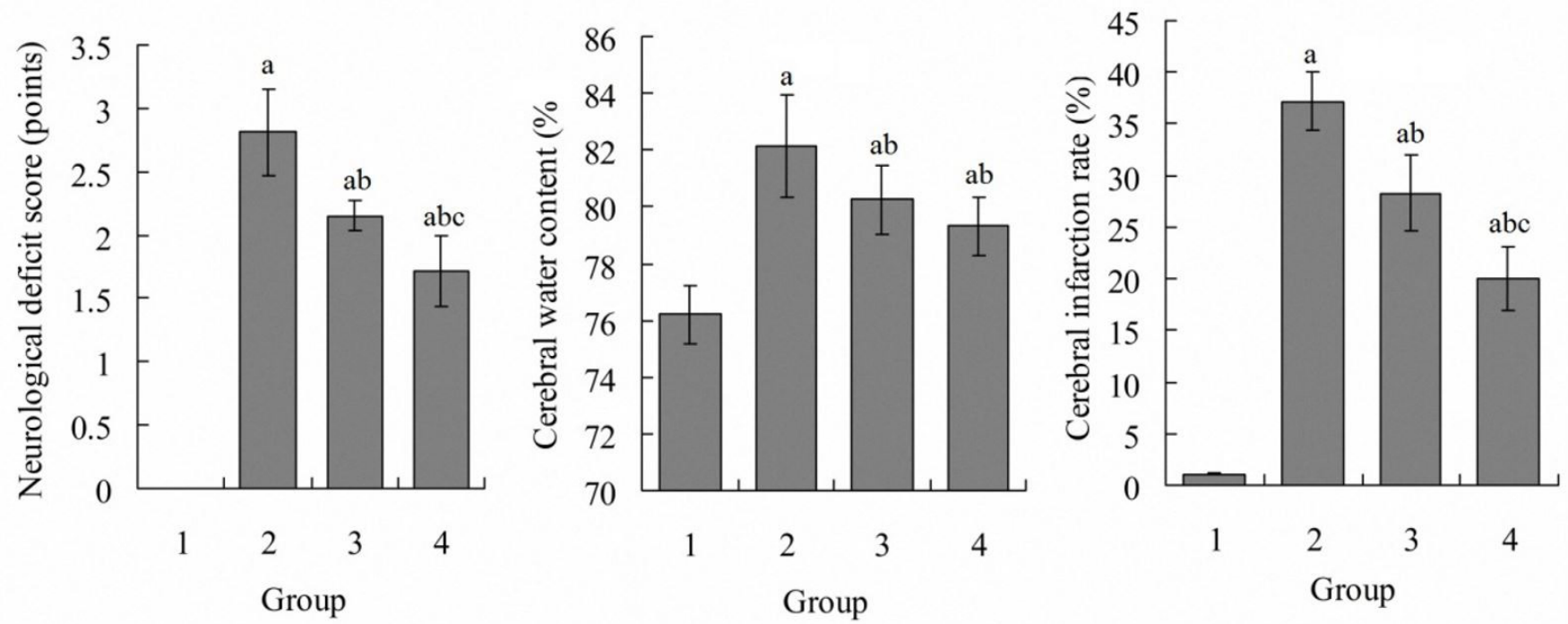

Figure 2. Comparisons of neurological deficit score, cerebral water content and cerebral infarction rate among four groups. ${ }^{a} \mathrm{P}<0.05$ vs. group 1 ; ${ }^{\mathrm{b}} \mathrm{P}<0.05$ vs. group 2 ; ${ }^{\mathrm{P}}<0.05$ vs. group 3. 1: sham-operated; 2: model; 3: formononetin; 4: nimodipine.
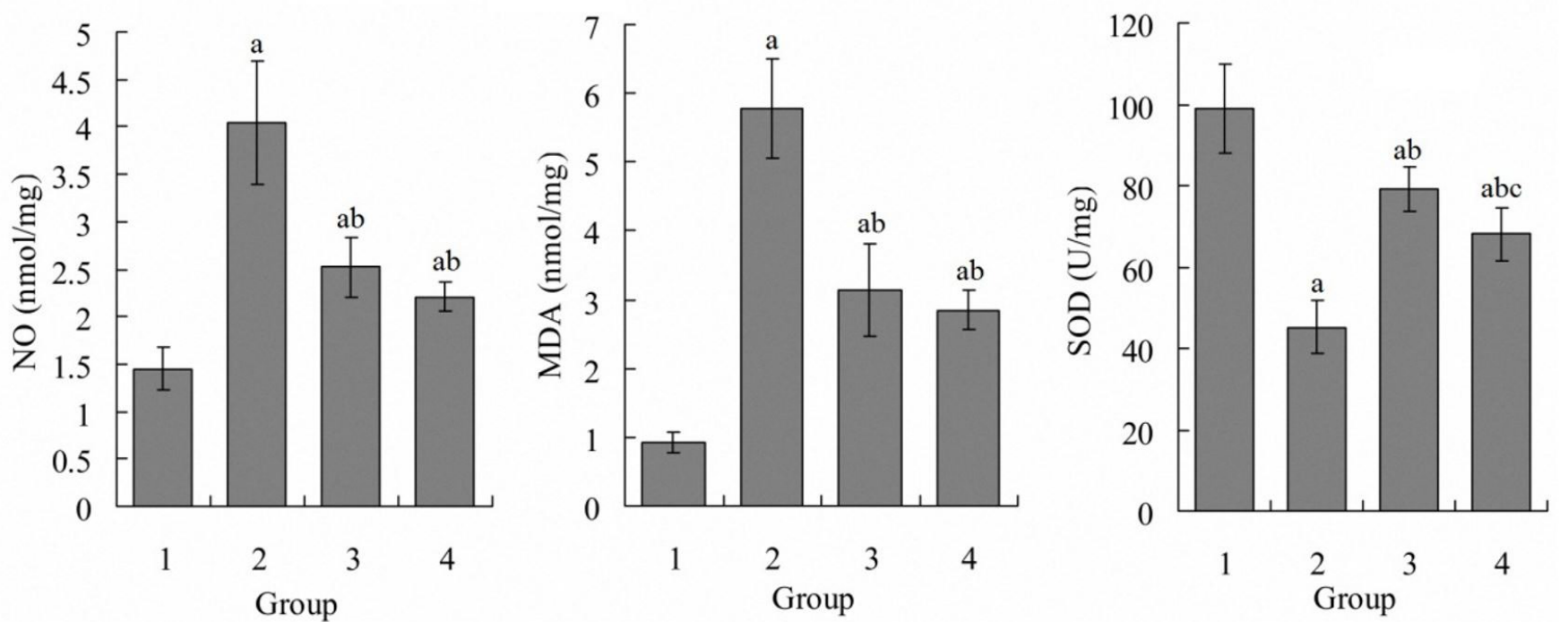

Figure 3. Comparisons of brain tissue NO, MDA and SOD levels among four groups. ${ }^{\mathrm{a}} \mathrm{P}<0.05$ vs. group 1 ; ${ }^{\mathrm{b}} \mathrm{P}<0.05$ vs. group 2 ; ${ }^{\mathrm{c}} \mathrm{P}<0.05$ vs. group 3. 1: sham-operated; 2: model; 3: formononetin; 4: nimodipine. NO, nitric oxide; MDA, malondialdehyde; SOD, superoxide dismutase. 
$(\mathrm{P}<0.05)$ decreased, respectively, and the SOD level was significantly $(\mathrm{P}<0.05)$ increased, respectively.

\subsection{Effects of formononetin on brain tissue energy metabolism indexes in CIRI mice}

After $24 \mathrm{~h}$ of reperfusion, compared with sham-operated group, the $\mathrm{Na}^{+}-\mathrm{K}^{+}$-ATPase and $\mathrm{Ca}^{2+}-\mathrm{Mg}^{2+}$-ATPase activities in model, formononetin and nimodipine groups and $\mathrm{Ca}^{2+}$-ATPase activity in model and formononetin groups were significantly $(\mathrm{P}<0.05)$ decreased, respectively. Compared with model group, in formononetin and nimodipine groups the $\mathrm{Na}^{+}-\mathrm{K}^{+}$-ATPase, $\mathrm{Ca}^{2+}-\mathrm{Mg}^{2+}$-ATPase and $\mathrm{Ca}^{2+}$-ATPase activities were significantly $(\mathrm{P}<0.05)$ increased, respectively (Figure 4$)$.

\subsection{Effects of formononetin on brain tissue inflammatory factor levels in CIRI mice}

As shown in Figure 5, after $24 \mathrm{~h}$ of reperfusion, the brain tissue TNF- $\alpha$ and IL- $1 \beta$ levels in model, formononetin and nimodipine groups and IL- 6 level in model and formononetin groups were significantly $(\mathrm{P}<0.05)$ higher than those in sham-
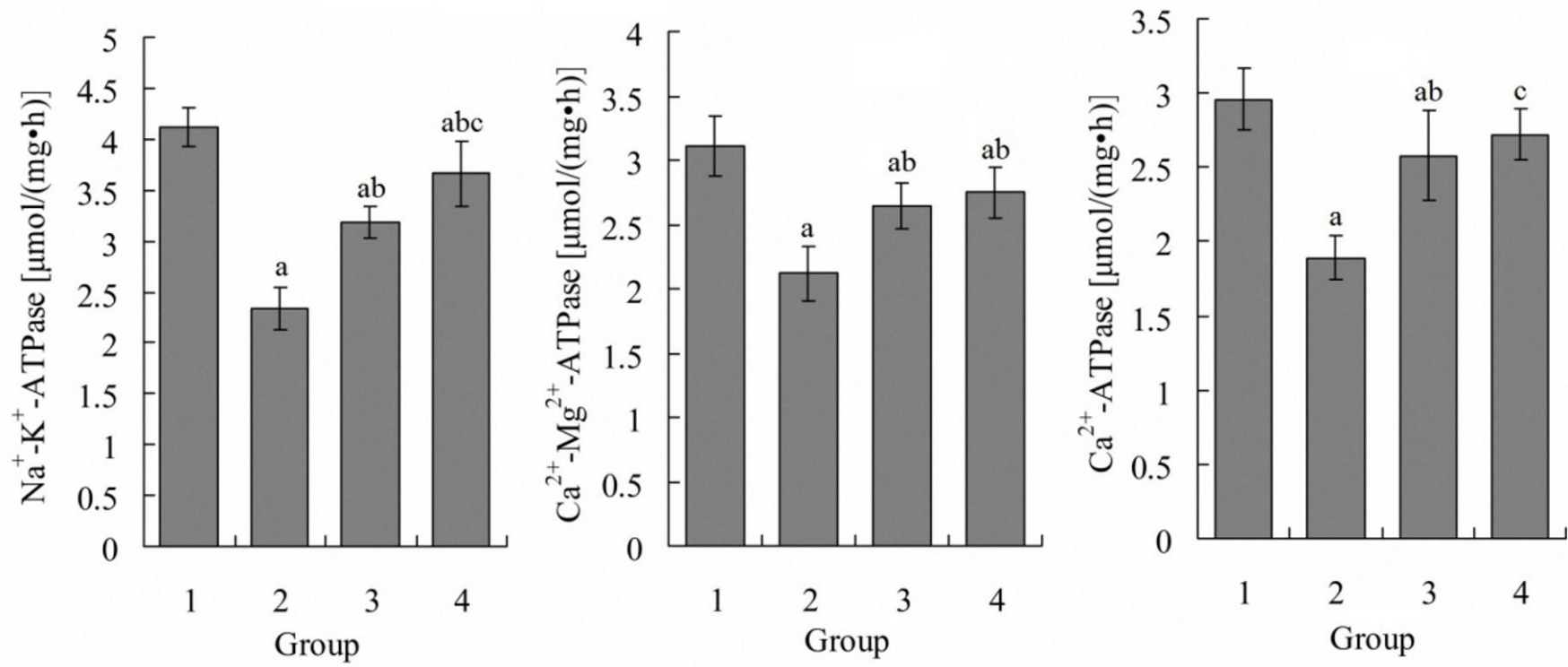

Figure 4. Comparisons of brain tissue $\mathrm{Na}^{+}-\mathrm{K}^{+}$-ATPase, $\mathrm{Ca}^{2+}-\mathrm{Mg}^{2+}$-ATPase and $\mathrm{Ca}^{2+}$-ATPase activities among four groups. ${ }^{\text {a }} \mathrm{P}<0.05$ vs. group 1 ; ${ }^{b} \mathrm{P}<0.05$ vs. group 2; ${ }^{\mathrm{P}}<0.05$ vs. group 3. 1: sham-operated; 2: model; 3: formononetin; 4 : nimodipine.
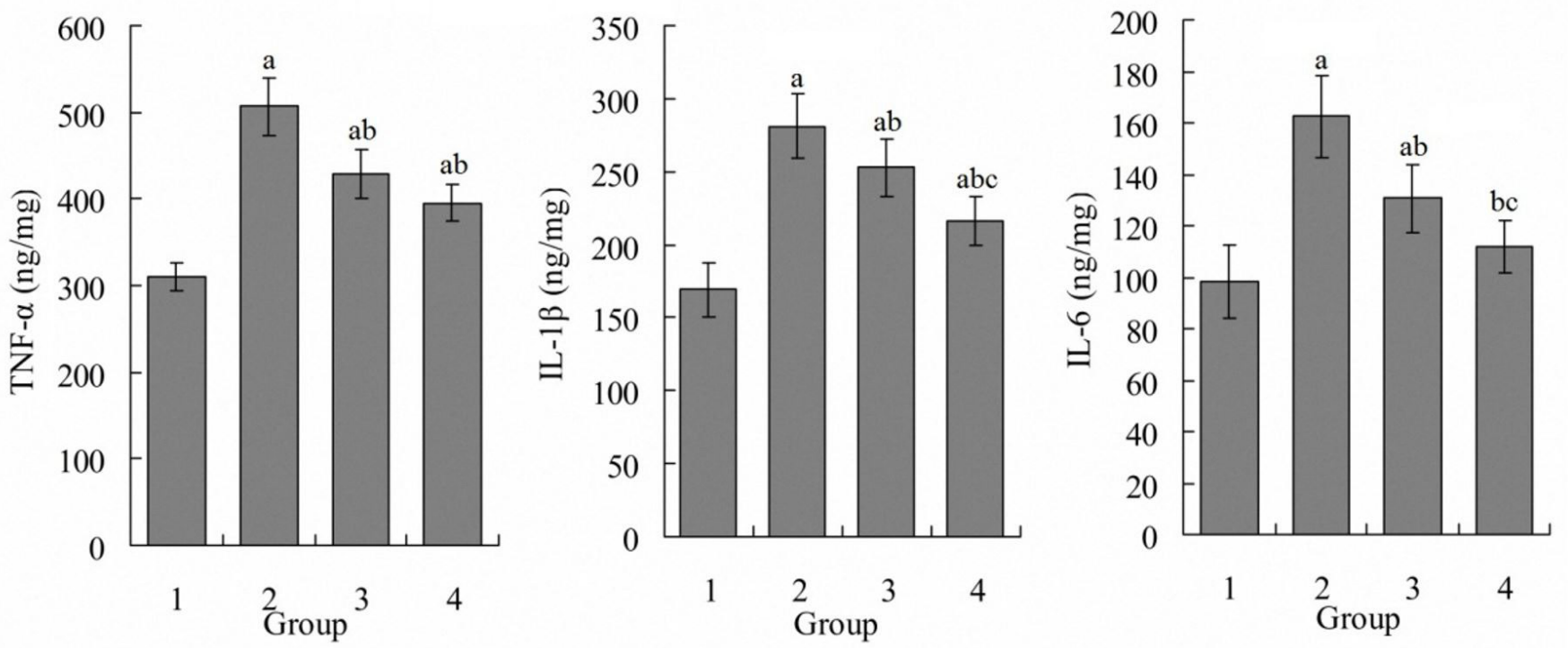

Figure 5. Comparisons of brain tissue TNF- $\alpha$, IL- $1 \beta$ and IL-6 levels among four groups. ${ }^{a} \mathrm{P}<0.05$ vs. group 1 ; ${ }^{\mathrm{b}} \mathrm{P}<0.05$ vs. group 2 ; ${ }^{\mathrm{c}} \mathrm{P}<0.05$ vs. group 3. 1: sham-operated; 2: model; 3: formononetin; 4: nimodipine. TNF- $\alpha$, tumor necrosis factor $\alpha$; IL-1 $\beta$, interleukin $1 \beta$; IL-6, interleukin 6. 
operated group, respectively. Each index in formononetin and nimodipine groups was significantly $(\mathrm{P}<0.05)$ decreased, respectively, compared with model group.

\section{Discussion}

The incidence rate of cerebral ischemia is increasing year by year, and there is no effective intervention method in clinic. Therefore, the treatment of CIRI has become a hot spot in the research of cerebrovascular disease. Studying the role and mechanism of natural medicine in mitigating CIRI can provide a new strategy for the prevention of nerve injury caused by ischemic stroke, and it is of great significance for the effective treatment of cerebrovascular disease and reducing the mortality (Wu et al., 2010; Li et al., 2015). In this study, the protective effect of formononetin from Trifolium pratense L. against CIRI in mice was evaluated. Results showed that, after $24 \mathrm{~h}$ of cerebral ischemia-reperfusion, the neurological deficit score, cerebral water content and cerebral infarction rate in model group were significantly higher than sham-operated group. This indicates that, the CIRI was successfully established. Compared with model group, each index in formononetin group was significantly decreased. This demonstrates that, the pre-administration of formononetin can mitigate the CIRI in mice.

CIRI can cause the production of a large number of oxygen free radicals in brain tissue, among which $\mathrm{NO}$ is a research hotspot. In the early stage of cerebral ischemia, NO produced by endothelial nitric oxide synthase (NOS) has neuroprotective effect, but its effect is very small. In the late stage of ischemia, especially the reperfusion stage, NO produced by neuronal NOS and inducible NOS can damage the nerve tissues (GürsoyÖzdemir et al., 2000; Dohare et al., 2008). MDA is the final product of lipid oxidation, and its level changes can indirectly reflect the changes of oxygen free radicals in tissues (Larsen et al., 2002). SOD, as the main enzyme of scavenging oxygen free radical, plays an important role in resisting oxygen free radical damage to cells (Kharb et al., 2000). In our study, after $24 \mathrm{~h}$ of reperfusion, the brain tissue $\mathrm{NO}$ and MDA levels in model group were significantly higher than sham-operated group, and the SOD level in model group was significantly lower than shamoperated group. This demonstrates that, the oxidative stress is involved in the CIRI of mice. Compared with model group, in formononetin group the $\mathrm{NO}$ and MDA levels were significantly decreased, and the SOD level was significantly increased. This confirms that, formononetin can reduce the oxidative stress in brain tissue, thus mitigating the CIRI in mice.

$\mathrm{Na}^{+}-\mathrm{K}^{+}$-ATPase, $\mathrm{Ca}^{2+}-\mathrm{Mg}^{2+}$-ATPase and $\mathrm{Ca}^{2+}$-ATPase are the proteases that exist on the biofilm. Their biological functions include energy conversion, material transport, information transport, and maintenance of intracellular and extracellular ion balance. During ischemia-reperfusion injury, the oxidative phosphorylation ability of cells is decreased. The ATP synthesis is decreased, with increased energy consumption and decreased $\mathrm{Na}^{+}-\mathrm{K}^{+}$-ATPase activity. So, the $\mathrm{Na}^{+}$and $\mathrm{K}^{+}$transport ability of cell membrane is impaired (Huang et al., 2015). At the same time, the $\mathrm{Ca}^{2+}-\mathrm{Mg}^{2+}$-ATPase and $\mathrm{Ca}^{2+}$-ATPase activities are decreased. The influx of $\mathrm{Ca}^{2+}$ is increased and the efflux is decreased, which causes the calcium overload, aggravating the secondary tissue injury (Qiao et al., 2011; Yan et al., 2017). In this study, after $24 \mathrm{~h}$ of reperfusion, compared with sham-operated group, the $\mathrm{Na}^{+}-\mathrm{K}^{+}$-ATPase, $\mathrm{Ca}^{2+}-\mathrm{Mg}^{2+}$-ATPase and $\mathrm{Ca}^{2+}$-ATPase activities in model group were significantly decreased. Compared with model group, each index in formononetin group was significantly increased. These findings indicate that, formononetin can reduce the energy metabolism impairment, which may be related to its protective effect on CIRI in mice.

More and more evidence shows that the inflammatory response plays an important role in ischemia-reperfusion injury (Oyama et al., 2004; Goebel et al., 2021). TNF- $\alpha$ is mainly produced by macrophages. It play a neurotoxic role by inhibiting NF- $\kappa \mathrm{B}$ pathway, promoting the expression of adhesion molecules, inducing the production of neurotoxic mediators, aggravating brain edema and increasing the permeability of blood-brain barrier (Dalvi et al., 2017). IL-1 $\beta$ and IL- 6 are also the important mediators of inflammatory response. The tissue ischemia-reperfusion activates the astrocytes and microglia to secrete a large amount of IL- $1 \beta$ and IL- 6 , which further aggravate the tissue injury (Kim et al., 2013). Results of this study showed that, after $24 \mathrm{~h}$ of reperfusion, the brain tissue TNF- $\alpha$, IL-1 $\beta$ and IL-6 levels in model group were significantly higher than sham-operated group. Each index in formononetin groups was significantly decreased, compared with model group. It is suggested that formononetin can mitigate the CIRI in mice by inhibiting the inflammatory response in brain tissues.

\section{Conclusion}

In conclusion, formononetin from Trifolium pratense L. can reduce the oxidative stress, energy metabolism impairment and inflammatory response in brain tissues, thus mitigating the CIRI in mice. Therefore, formononetin has beneficial effect on CIRI in mice and may be developed as a potential candidate for prevention and treatment of CIRI. Of course, our study is only a preliminary experiment on the protection of formononetin on CIRI. Maybe other mechanisms are involved in the action formononetin, but they are not investigated here. This is a limitation of our study, and should be solved in further researches.

\section{Conflict of interest}

The authors declare that they have no conflict of interest.

\section{References}

Cavendish, R. L., Santos, J. S., Neto, R. B., Paixão, A. O., Oliveira, J. V., Araujo, E. D., Silva, A. A. B., Thomazzi, S. M., Cardoso, J. J., \& Gomes, M. Z. (2015). Antinociceptive and anti-inflammatory effects of Brazilian red propolis extract and formononetin in rodents. Journal of Ethnopharmacology, 173, 127-133. http://dx.doi.org/10.1016/j. jep.2015.07.022. PMid:26192808.

Chen, J., Zeng, J., Xin, M., Huang, W., \& Chen, X. (2011). Formononetin induces cell cycle arrest of human breast cancer cells via IGF1/ PI3K/Akt pathways in vitro and in vivo. Hormone and Metabolic Research, 43(10), 681-686. http://dx.doi.org/10.1055/s-0031-1286306. PMid:21932171.

Costa, G. L. A., Buccini, D. F., Arruda, A. L. A., Favaro, S. P., \& Moreno, S. E. (2020). Phytochemical profile, anti-inflammatory, antimutagenic and antioxidant properties of Acrocomia aculeata (Jacq.) Lodd. 
pulp oil. Food Science Technology, 40(4), 963-971. http://dx.doi. org/10.1590/fst.25319.

Dalvi, P. S., Chalmers, J. A., Luo, V., Han, D. Y., Wellhauser, L., Liu, Y., Tran, D. Q., Castel, J., Luquet, S., Wheeler, M. B., \& Belsham, D. D. (2017). High fat induces acute and chronic inflammation in the hypothalamus: effect of high-fat diet, palmitate and TNF- $\alpha$ on appetite-regulating NPY neurons. International Journal of Obesity, 41(1), 149-158. http://dx.doi.org/10.1038/ijo.2016.183. PMid:27773938.

Dohare, P., Varma, S., \& Ray, M. (2008). Curcuma oil modulates the nitric oxide system response to cerebral ischemia/reperfusion injury. Nitric Oxide, 19(1), 1-11. http://dx.doi.org/10.1016/j.niox.2008.04.020. PMid:18485279.

Goebel, U., Scheid, S., Spassov, S., Schallner, N., Wollborn, J., Buerkle, H., \& Ulbrich, F. (2021). Argon reduces microglial activation and inflammatory cytokine expression in retinal ischemia/reperfusion injury. Neural Regeneration Research, 16(1), 192-198. http://dx.doi. org/10.4103/1673-5374.290098. PMid:32788476.

Gürsoy-Özdemir, Y., Bolay, H., Saribaş, O., \& Dalkara, T. (2000). Role of endothelial nitric oxide generation and peroxynitrite formation in reperfusion injury after focal cerebral ischemia. Stroke, 31(8), 19741981. http://dx.doi.org/10.1161/01.STR.31.8.1974. PMid:10926966.

Hu, J. X., Gao, J. Y., Zhao, Z. J., \& Yang, X. (2021). Response surface optimization of polysaccharide extraction from Galla Chinensis and determination of its antioxidant activity in vitro. Food Science Technology, 41(1), 188-194. http://dx.doi.org/10.1590/fst.38619.

Huang, H., Chen, Y. M., Zhu, F., Tang, S. T., Xiao, J. D., Li, L. L., \& Lin, X. J. (2015). Down-regulated $\mathrm{Na}(+) / \mathrm{K}(+)$-ATPase activity in ischemic penumbra after focal cerebral ischemia/reperfusion in rats. International Journal of Clinical and Experimental Pathology, 8(10), 12708-12717. PMid:26722460.

Kanadys, W., Baranska, A., Jedrych, M., Religioni, U., \& Janiszewska, M. (2020). Effects of red clover (Trifolium pratense) isoflavones on the lipid profile of perimenopausal and postmenopausal women-A systematic review and meta-analysis. Maturitas, 132, 7-16. http:// dx.doi.org/10.1016/j.maturitas.2019.11.001. PMid:31883666.

Kharb, S., Singh, V., Ghalaut, P. S., Sharma, A., \& Singh, G. P. (2000). Role of oxygen free radicals in shock. The Journal of the Association of Physicians of India, 48(10), 956-957. PMid:11200917.

Kim, J. H., Song, A. R., Sohn, H. J., Lee, J., Yoo, J. K., Kwon, D., \& Shin, H. J. (2013). IL-1 $\beta$ and IL-6 activate inflammatory responses of astrocytes against Naegleria fowleri infection via the modulation of MAPKs and AP-1. Parasite Immunology, 35(3-4), 120-128. http:// dx.doi.org/10.1111/pim.12021. PMid:23198898.

Larsen, M., Webb, G., Kennington, S., Kelleher, N., Sheppard, J., Kuo, J., \& Unsworth-White, J. (2002). Mannitol in cardioplegia as an oxygen free radical scavenger measured by malondialdehyde. Perfusion, 17(1), 51-55. http://dx.doi.org/10.1191/0267659102pf528oa. PMid:11817530.

Li, L., Yang, N., Nin, L., Zhao, Z., Chen, L., Yu, J., Jiang, Z., Zhong, Z., Zeng, D., Qi, H., \& Xu, X. (2015). Chinese herbal medicine formula tao hong si wu decoction protects against cerebral ischemiareperfusion injury via PI3K/Akt and the Nrf2 signaling pathway. Journal of Natural Medicines, 69(1), 76-85. http://dx.doi.org/10.1007/ s11418-014-0865-5. PMid:25149059.
Longa, E. Z., Weinstein, P. R., Carlson, S., \& Cummins, R. (1989). Reversible middle cerebral artery occlusion without craniectomy in rats. Stroke, 20(1), 84-91. http://dx.doi.org/10.1161/01.STR.20.1.84. PMid:2643202.

Medjakovic, S., \& Jungbauer, A. (2008). Red clover isoflavones biochanin $\mathrm{A}$ and formononetin are potent ligands of the human aryl hydrocarbon receptor. The Journal of Steroid Biochemistry and Molecular Biology, 108(1-2), 171-177. http://dx.doi.org/10.1016/j. jsbmb.2007.10.001. PMid:18060767.

Oyama, J., Blais, C. Jr, Liu, X., Pu, M., Kobzik, L., Kelly, R. A., \& Bourcier, T. (2004). Reduced myocardial ischemia-reperfusion injury in tolllike receptor 4-deficient mice. Circulation, 109(6), 784-789. http:// dx.doi.org/10.1161/01.CIR.0000112575.66565.84. PMid:14970116.

Qiao, Z., Ma, J., \& Liu, H. (2011). Evaluation of the antioxidant potential of Salvia miltiorrhiza ethanol extract in a rat model of ischemiareperfusion injury. Molecules, 16(12), 10002-10012. http://dx.doi. org/10.3390/molecules161210002. PMid:22138858.

Sultan, M. T., Aslam, F., Rasool, B., Imran, M., Ahmad, A. N., Tariq, H. B., Afzal, M. I., Rehman, H., Shahbaz, M., \& Nadeem, M. (2021). Nigella sativa ameliorates oxidative stress induced adverse effects in rodent modeling studies: Indices of serum chemistry and hematology. Food Science Technology, 41(2), 404-411. http://dx.doi. org/10.1590/fst.01120.

Sun, T., Wang, J., Huang, L. H., \& Cao, Y. X. (2013). Antihypertensive effect of formononetin through regulating the expressions of eNOS, 5 -HT2A/1B receptors and $\alpha 1$-adrenoceptors in spontaneously rat arteries. European Journal of Pharmacology, 699(1-3), 241-249. http://dx.doi.org/10.1016/j.ejphar.2012.10.031. PMid:23123056.

Wang, D. S., Yan, L. Y., Yang, D. Z., Lyu, Y., Fang, L. H., Wang, S. B., \& Du, G. H. (2020). Formononetin ameliorates myocardial ischemia/ reperfusion injury in rats by suppressing the ROS-TXNIP-NLRP3 pathway. Biochemical and Biophysical Research Communications, 525(3), 759-766. http://dx.doi.org/10.1016/j.bbrc.2020.02.147. PMid:32145915.

Wang, J. J., Zhu, J. D., Zhang, X. H., Long, T. T., Ge, G., \& Yu, Y. (2019). Neuroprotective effect of Notch pathway inhibitor DAPT against focal cerebral ischemia/reperfusion 3 hours before model establishment. Neural Regeneration Research, 14(3), 452-461. http:// dx.doi.org/10.4103/1673-5374.245469. PMid:30539813.

Wu, P. F., Zhang, Z., Wang, F., \& Chen, J. G. (2010). Natural compounds from traditional medicinal herbs in the treatment of cerebral ischemia/ reperfusion injury. Acta Pharmacologica Sinica, 31(12), 1523-1531. http://dx.doi.org/10.1038/aps.2010.186. PMid:21127495.

Yan, X., Li, H., Bai, M., \& Miao, M. (2017). Effect of total flavonoids of Radix Ilicis pubescentis on cerebral ischemia reperfusion model. Saudi Journal of Biological Sciences, 24(3), 595-602. http://dx.doi. org/10.1016/j.sjbs.2017.01.031. PMid:28386185.

Zhang, X., Wang, X., Xue, Z., Zhan, G., Ito, Y., \& Guo, Z. (2021). Prevention properties on cerebral ischemia reperfusion of medicine food homologous Dioscorea yam-derived diosgenin based on mediation of potential targets. Food Chemistry, 345, 128672. http:// dx.doi.org/10.1016/j.foodchem.2020.128672. PMid:33352403. 